\title{
The Concept of Orientalist Writings With Special Reference to Joseph Conrad's Heart of Darkness and E. M. Forster's A Passage to India
}

\author{
Arivarasy Muthulingam \\ University of Jaffna, Jaffna, Sri Lanka
}

\begin{abstract}
This paper aims to analyse Joseph Conrad's Heart of Darkness and E. M. Forster's A Passage to India from Orientalist perspective. The term "Orientalism" became a watermark with Edward Said as an intellectual term. According to Said, Orientalism generates a series of stereotypical dichotomy between the masculine "West" and the feminine "East". Said's project is to show how knowledge of Europe about the non-Europeans was part of the process of maintaining power over them. Both novels Heart of Darkness and A Passage to India deal with the socially and culturally subordinate groups regarding the definition of subjectivity and the production of knowledge. These novels produce its representation of the Orient in terms of unchangeable stereotypes and reductive categories. But from Orientalist view, in Heart of Darkness, Africa is personified in a way to resist against the subjugation of European countries. Forster in A Passage to India shows how colonialism creates a false illusion that the west is "self" and the East is "other". Analytical and comparative methods are planned to be used. The qualitative methodology of the research will be carried out through texts, journals, articles and informal interviews. The objective is to pinpoint that both these novels are resistant readings against the imperial politics from Edward Said's Orientalist perspective. Said confirms it as a strategy of resistance that makes the colonized natives on the very terrain of imperial language and discourse.
\end{abstract}

Keywords: power, subjectivity, resistant, truth

\section{Introduction}

The aim of this study is to examine the colonial novels Heart of Darkness by Joseph Conrad and A Passage to India by E. M. Forster from Edward Said's Orientalist perspective. The term "Orientalism" has become highly problematic. Orientalism carries forward two traits: (1) A newly found scientific self-consciousness based on the linguistic importance of the Orient to Europe and (2) A proclivity to divide, subdivide and re-divide its subject matter without changing its mind about the Orient as being always the same unchanging, uniform and radically peculiar object.

Arivarasy Muthulingam, B.A. English Literature (Special), Assistant Lecturer, Department of Linguistics \& English, University of Jaffna.

Correspondence concerning this article should be addressed to Arivarasy Muthulingam, 91/8 Hindu Ladies Lane, Kandarmadam, Jaffna, Sri Lanka. 


\section{History of Orientalism}

The history of intellectual, political and cultural contact between East and West is convoluted, full of ambiguities, enigmas and contradictions. The idea of orientalism fluctuates from time to time. There have been attempts to theorize the western fascination with the East. S. Radhakrishnan, the eminent Indian philosopher has written of the west's attraction to "the glamour of the exotic" and has remarked that "The East has ever been a romantic puzzle to the West, the home of adventures like those of the Arabian Nights, the abode of magic, the land of hearts' desire" (Eastern Religions and Western Thought, p. 251). In the classical Orientalism Christian authors witnessing the Islam conquests had scant interest in the learning of high culture and frequent magnificence of the Muslims Orient. Since the time of colonialism the East has also been depicted not only as exotic, mysterious and alluring but as malignant, dark, threatening. Robert Bridges in The Testament of Beauty says that in the past the West looked to the East for spiritual wisdom and East is now dazzled by the material conquests of the west. The Enlighenment Philosophies had been much attracted to the Chinese civilization. Writers like Voltaire, Diderot, Helvettius and David Hume extolled the virtues of many aspects of Chinese civilization, particularly Confusianism which they understood as a rationally-based and humanistic system of social ethics. Orientalism became the catalyst for nationalism in the later colonial period. Discovery of ancient manuscripts and texts, monuments and sites gave the nationalists the historical continuity and cultural identity. It is essential for the struggle for nationhood. Most influential of all theorization about Orientalism in recent years has been Edward Said's widely celebrated Orientalism in which he argued that the Orient was a "system of ideological factions" whose purpose was to legitimize western cultural and political superiority, furthermore the western understanding of the East had grown out of a relationship of power, of domination, of varying degrees of cultural hegemony (Said, 1995, pp. 321-325). Said's argument addressed primarily to European encounter with Islam and with the Middle East, although Said himself extends the case to the Orient in general. From the late 18th to the 20th century, Orientalism remained a more or less neutral descriptive term, with a cluster of both positive and negative connotations. Though it is a volatile term it became a watermark with Edward Said in the history of Orientalism, both as a term and as an intellectual term.

\section{Edward Said's Orientalism}

Orientalism has been, after all a political vision of reality between the European/the West/us and the Orient/the East/them. Orientalism, conception of western strength and Eastern weakness has been intrinsic to the discourse. The significant elements in defining the relation between the Occident and the Orient were the vastly increased systematic knowledge about of Orient in Europe. The writer must organize the Orient, locate himself in relation to it and finally represent it or speak on its behalf. The object and fact of Orientalism is a fluid entity. Orientalism has valued Europe more highly in almost every aspect proposed for comparison. The discourse of postcolonial is therefore grounded on a struggle for power-that power focused in the control of metropolitan language. Power is invested in the language because it provides the terms in which the truth itself is constituted. Said pronounces that the negative emergence of Orientalist structures could be reduced if the East starts to speak itself. Said highlights that "East cannot represent themselves, they must be spoken for" (Said, 1995, p. 21).

Said puts forward several definitions of orientalism in the introducing to "Orientalism":

- "Orientalism, a way of coming to terms with the Orient that is based on the Orient's special place in European western experience.” (p. 1) 
- “...Particularly valuable as a sign of European Atlantic power over the Orient that is as a veridic discourse about the orient." (p. 3)

- “A style of thought based upon an ontological and epistemological distinction made between the 'orient' and the 'occident'." (p. 2)

- “A westerns style for dominating, restructuring and having authority over the orient.” (p. 8)

- "A distribution of geopolitical awareness into aesthetic, scholarly economic, sociological, historical and philological text.” (p. 12)

- Orientalism as a dynamic exchange between individual authors and the large political concerns shaped by the three great empires. British, French, America in whose intellectual and imaginative territory the writing was produced. (p. 15)

- Orientalism was ultimately a political vision of reality whose structure promoted the difference between the familiar (Europe, the West, "us") and the strange (the Orient, the East, “them”). (p. 14)

- As Said claims, the westerners have been able to "penetrate”, "wrestle with" and "give shape and meaning" to the mysteries of the Orient. Orientalism, conception of the western strength and Eastern weakness has been intrinsic to the discourse. The most intellectual question evoked in Orientalism by Said.

- Can one divide human reality, as indeed human reality seems to be generally "divided, into clearly different cultures, histories, traditions, societies, even races and survive the consequences humanity (?) (...) (Is there) anyway of avoiding to hostility expressed by the division, say of men into "us", "westerners" and "them". When one uses categories like Oriental and western as both the starting and the end points of analysis, research, public policy (...) The Oriental becomes more Oriental, the westerner more western and limit the human encounter between different cultures, tradition and societies (Said, 1995, p. 89).

Undoubtedly, as Said claims, there have been fundamental misrepresentations of Islam in the west. He ponders the question whether there can be true representations of anything. And perhaps all representations are of necessity, entrenched in language, culture and political context and shaped by institutions.

Thus the history of Orientalism has both an internal consistency and a highly articulated set of relationships to the dominant culture surrounding (Said, 1995, pp. 20-21).

A significant issue in studying Orientalism is obviously the definition of "Oriental". In Said's view, the term has been canonically by a wide range works, in the works of scholarships. To him, British supremacy was not so much related to military or economic power but with "knowledge" over Egypt. The British were able to survey Egyptian civilization from its beginning. The object and the fact of Orientalism is a fluid entity that changes as civilizations do, but in a fundamental ontological way it is stable. In Balfour's speech, Egyptian inferiority is taken for granted and the blessing of the Egyptians is to have a superior nation like Britain to occupy them. Said notices that it never occurs to Balfour to let the Egyptians speak for themselves. As Said reads Balfour, the races which are colonized do not appreciate or even understand the good of being colonized. For Balfour, every Egyptian who does indeed "speak for himself" is an agitator and an indecent native unappreciative of England's altruistic act of occupation.

What distinguishes Orientalism from other stereotyping and "othering" discourses is the European position of strength or even domination in relation to the Orient. The "weak Orient" was contrasted with "the powerful Europe" although the relationship was often disguised in admiring the "greatness of the ancient civilizations of the Orient". Orientalism has valued Europe more highly in almost every aspect proposed for comparison, whether it is in politics, culture or religion. 
The rational, virtuous and mature European has been able to see the irrational, depraved and childlike Oriental. As a result, the Oriental has become something one can judge, study, discipline and illustrate and hence contain and represent (Said, 1995, p. 40).

In Said's view, colonialists equated the colour of their skin with a "superior ontological status" and the power to rule the rest of the world. Being a white Man was self-confirming. "One became a White Man because one was a White Man. It was a destiny that left little time for seeking casual explanations from history.” In addition to being regulated by norms of behavior suitable for distinguished white male gentleman, being a white Man meant specific judgements and evaluations. Only an Occidental could speak of Orientals and only the white Man could identify and designate the non-whites. Typologies distanced the non-whites from the white and traditions and education kept the oriental/Coloured in his separate place for the Occidental white to study him (Said, 1995, pp. 226-228). Naturally, racial theory, rising imperialism and the incomplete and inadequately assimilated sciences reinforced each other. Ontological and empirical truths combined with the study of origins, development, character and destiny gave these destinations validity.

\section{Resisting Orientalism}

The Orient rebelled against European domination and thus constituted a challenge to western power over it and to western spirit and knowledge. Moral questions about Europe's encroachment in the orient, European treatment of Orientals and Oriental Nationalist movements and so forth arose and became more delicate and acute. Europeans would have to penetrate native societies with more vigour and better perceptions and discover their fundamental values to offer European understanding. A transformation of Orientalism was needed for the indigenous political insurgencies. Orientalism as an academic discipline was thought to widen western vision only to serve colonialism. As the demands for native independence grew, the notion "natural” colonization and the need for European enlightenment to the Orient diminished. But the perception is that the west and the East were two separate entities.

As Said, "it was believed, then, that for the Oriental, liberation, self-expression and self enlargement were not the issues that they were for the Occidental" (Said, 1995, p. 121). To Said, Orientalism even seemed to resist the attempts at mutual comprehension between the East and the West and the modernizing of gender roles. So, the deep was the resistance to change.

Said mentions Karl Marx’s “The Eighteenth Brumaire of Louis Bonarparte” (1852) highlighting western thinking regarding the East that "East cannot represent themselves, they must be spoken for" (Said, 1995, p. 21). Said pronounces that the negative emergence of Orientalist structures could be reduced if the East starts to speak itself. There is no doubt to the fact that Orientalism is a way of conceiving post-colonialism and postmodernism. Moreover, it has been recognized as a powerful discipline whose principles are hard enough to deconstruct. It is admirable that Said had demonstrated Orientalism from multiple points of view with textual evidences of varied implicit and explicit interpretations. But his work has always been sharply criticized by many intellectuals.

\section{An Analysis of Heart of Darkness}

In Conrad's Heart of Darkness, Africa as an object is condemned to a sense of the resistance of the world and of the utter deprivation of truth by Europeans. Colonizers justify themselves as civilizers and the bearers of a light that is kindled by a "spark from the fire". The British Empire was justified because real work was done 
in it and by implication the imperialism of other countries had no justification. From an Orientalist view, Africa is personified in a way to resist against the subjugation of European countries in Heart of Darkness. European metropolis symbolizes the repressive social mechanism the civilized world has developed in order to ensure a smooth and peaceful existence. The principle of finality, casuality and rationality finds expression in the white characters. The loss of norms which constituted the reality of human relationships in the civilized world is demonstrated in the so called white man. Marlow's representation in the novel can be taken as an exemplary of Orientalist view, that is the one can escape from the unhappy cycle of life and death in which human beings are trapped. In Heart of Darkness, there are references to England itself having once been a dark place that attracted alien conquerors. The imagery of Africa which Conrad depicts in the novella is highly influenced by his own experiences in the African territories, especially his journey to the Congo and it highlights the concept of Orientalist writings too. He found the concrete image of drum to express the important aspects and provide a critique of Belgian colonialism. The Congo experience was to give him new insight into human nature where the usual pattern was completely reversed; whiteness and light may turn out to blackness and darkness may relatively be pure.

\section{An Analysis of a Passage to India}

In A Passage to India, Forster's India is hostile to foreigners and attacks its colonizers ferociously. The manner in which all Indian characters portrayed echoes an undercurrent of inauthenticity, simulating in this regard where the "other" features were understood through the old narratives. The colonizers claim that they have the mission of "bringing light" to the colonized as ignominious darkness (Memmi, 1979, pp. 74-76). The mission legitimizes the colonization and distances of other races. Edward Said notes the depiction of colonized races as being "naturally subservient, advances, developed and morally mature Europe” (Eagleton, 1990, p. 72). Fielding like Forster felt the barrier between colonizer and the colonized. He states that "the sense of racial tension of compatibility, never left me” (p. 315). His love for the Indians is well-established and so his love for the country. Fielding and Forster denounce colonization and this explains the contradiction in their attitude towards colonization. In the same vein, Fielding's helpless question "why can't we be friends now?" is answered by multitudes of voice. Towards the end of A Passage to India, Aziz’s angry attitude towards Fielding is a germanous exposure of the Indian spirit of nationalism. His angry reaction to fielding's mockery remark "who do you want instead of the English?" appears to be an outburst of nationalism. As Forster puts it, "Down with English anyhow. That's certain clear out, you fellows, double quick I say.” Dr. Aziz anticipates with remarkable social and most post-colonial nationalisms of the Islamic world. Said's upward mobility is a necessary means to gain counter authority to "speak truth to power". Forster gives the colonized a voice to defend their rights and to express their attitudes and feelings regardless the colonizer's practices. These two novels propose internal resistance by a secular interrogation of identitarian thoughts.

\section{Conclusion}

Both novels have contributed to and participated in the imperial politics that "classifies and reinforces the feelings and attitudes of colonizers". Said accepts the necessity to understand real history through texts. Said calls for critics to take responsibility for "articulating the voices dominated, displaced or silenced by the textuality of texts". Said confirms Orientalism as a strategy of resistance that makes the colonized natives speak on the very terrain of imperial language and discourse. 
The qualitative methodology of the research will be carried out through texts, journals, articles and informal interviews. The object is to pinpoint that both these novels are resistant readings against the imperial politics from Edward Said's Orientalist perspective. Thus I attempt to analyse, compare, and contrast Heart of Darkness and A Passage to India on the basis of Orientalist perspective.

\section{References}

Abraham, W. E. (1962). The mind of Africa. London: Weidenfeld and Nicolson.

Achebe, C. (1988). An image of Africa: Racism in Conrad's Heart of Darkness. In R. Kinbrough (Ed.), Joseph Conrad Heart of Darkness (Norton Critical Edition). London: W. W Norton and Co.

Adam, H. (1999). King Leopold's ghost: A story of greed, terror and heroism in colonial Africa. New York: Mariner Books.

Alatas, H. (1977). The myth of the lazy native. London: Frank Cass.

Almond, P. C. (1989). The British discovery of Buddhism. United States of America: Indiana University Press.

Ambrosini, R. (1991). Conrad's fiction as critical discourse. United Kingdom: Cambridge University Press.

Ashcroft, G., \& Tiffin. (1989). The empire writes back-theory and practice in post-colonial literatures. London: Routledge Taylor \& Francis Group.

Bahr, L. S., \& Johnson, B. (Eds.). (1991). Collier’s encyclopaedia. (Vol. 1). Oxford: Maxwell Macmillan International Publishing Group.

Batchelor, S. (1994). The awakening of the West: The encounter of Buddhism culture. Berkeley, Calif: Parallax Press.

Bear, J. B. (1962). The achievement of E. M. Forster. London: Chatto and Windus Ltd.

Childs, P. (Ed.). (1999). Post-colonial theory and English literature. Edinburgh: Edinburgh University Press.

Conrad, J. (1975). Heart of darkness. Harmondsworth: Penguin.

Forster, E. M. (2005). A passage to India. London: Edward Arnold.

Memmi, A. (1967). The colonizer and the colonized. Boston: Beacn Press.

Radhakrishnan, S. (1962). Eastern religions and western thought. India: Oxford University Paperbacks.

Said, E. (1995). Orientalism western conceptions of the orient. London: Routledge \& Kegan Paul Ltd. 